\title{
DeTERmination OF WATER Quality STATUS BaSEd On Heavy Metal CONTENTS IN THE RAINY AND DRY SEASON USING THE STORET INDEX IN Pasuruan Sea Waters, East Java
}

\author{
Endang Yuli Herawatia*, Diana Arfiatia ${ }^{a}$, Pratama Diffi Samuel ${ }^{\text {a }}$, Karina Farkha Dina ${ }^{a}$, \\ Putri Anugerah $^{\mathrm{b}}$ and Rahmi Valina ${ }^{\mathrm{a}}$ \\ ${ }^{a}$ Faculty of Fisheries and Marine Sciences, Universitas Brawijaya, Malang, Indonesia \\ ${ }^{\mathrm{b}}$ Faculty of Agriculture, Universitas Asahan, Kisaran, Indonesia \\ *Corresponding author (E-mail address): herawati_ey@ub.ac.id
}

\begin{abstract}
Waters that are presumably contaminated with heavy metals need to be observed to ensure the level of pollution to perform water restoration This study aims to determine the status of water quality based on the content of heavy metals in the dry season and rainy season. The survey method was employed in this study, and it was conducted in Pasuruan sea waters in different seasons; September 2019 represented the dry season, and April 2020 represented the rainy season. The water sampling stations were chosen by using purposive sampling in three sampling locations: the sea waters of Kraton, Lekok, and Nguling districts. The heavy metals and water quality parameters were analyzed by using Storet Index. The results indicated that the highest level of heavy metals was found in Lekok waters in September, consisting of $\mathrm{Hg}(1.22 \mathrm{mg} / \mathrm{l}), \mathrm{Cd}(1.20$ $\mathrm{mg} / \mathrm{l})$, and $\mathrm{Pb}(0.55 \mathrm{mg} / \mathrm{l})$. The seawater of Nguling district had the lowest content in April, while Kraton's seawater was moderate. The water quality status based on the Storet Index suggested that the sea waters of Kraton, Lekok, and Nguling districts were classified as moderately polluted with a score of -16 to -24 . The highest score was in September in the rainy season with a score of -24 and the score in April in the dry season was -16. It means that the score is increasing but still in the moderately polluted category. The measurement results of temperature, $\mathrm{pH}$, dissolved oxygen, salinity, and current velocity were in optimum results for aquatic organisms in the dry season or the rainy season. Regarding the water quality status in Pasuruan sea waters, it can be concluded that the heavy metal contents exceeded the quality standard set by the government. Therefore, improved management is required to prevent the deterioration of the pollution status in Pasuruan sea waters.
\end{abstract}

Keywords: Pasuruan sea waters, season, heavy metal, Storet Index

\section{INTRODUCTION}

Pasuruan Sea is one of the strategic waters in East Java Province, located in the relatively densely populated Madura Strait. Pasuruan Regency has three capture fisheries centers located respectively in Kraton, Lekok and Nguling Districts with a total of 12,059 fishing households and 2,281 fishing fleets. Lekok sub-district is the largest capture fishery center with 5,723 fishing households and 1,621 fishing fleets. The surrounding community has utilized these waters for fishing business using a static "stick-on chart" tool and catching fish that are actively hunting, namely nets and fishing rods. Around the Pasuruan coast is also used for aquaculture. The waste from this aquaculture business will eventually enter the sea as well as other waste that enters the river. All of these activities will affect the quality of sea water [1].

In the survey and preliminary research activities, the results of analysis of heavy metals in water were obtained, namely: Cadmium (Cd) $1.51 \mathrm{mg} / \mathrm{l} \mathrm{mg/l}$ (Standard quality standard Cd 0.01); Mercury (Hg) 1.39 $\mathrm{mg} / \mathrm{l}$ (Standard quality standard $\mathrm{Hg}$ 0.0010.005); Lead (Pb) 0.6 mg/l (Standard Pb 0.03). Based on these results it can be seen that the value of heavy metals obtained exceeds the quality standard threshold. Pasuruan Regency is located in a basin and is also the area closest to the estuary area of the Porong River which is a tributary of the Brantas river. The waste that is carried from the Porong River to the sea is likely to enter the coastal area and rivers in 
Pasuruan Regency, including the coastal waters of Lekok [2].

Pasuruan as one of the high producers of shellfish and fish. Lekok Beach received input from the Rejoso River and several small tributaries where in the previous section there were residential areas, industrial and agricultural activities which also had the potential to dump their waste into the river which would eventually reach the sea [3]. research results show that the highest concentration of $\mathrm{Pb}$ in water in winding waters is $0.444 \mathrm{mg} / \mathrm{l}$. The results showed that the heavy metal $\mathrm{Pb}$ had passed the safe threshold. The waters of Lekok have been contaminated with heavy metals which were examined from water, sediment and blood shells, in curved blood shells with a heavy metal lead of 0.50 ppm; Cd of $0.41 \mathrm{ppm}$; $\mathrm{Zn}$ of $11.27 \mathrm{ppm}$ and blood clam meat is not safe for consumption because it exceeds the set standard. The impact of this pollution is thought to have an impact on marine life.

\section{METHOD}

The method of determining the water sampling station was carried out by purposive sampling, namely the determination of the observation station was carried out by considering various considerations of the conditions and conditions of the research location which were thought to have an effect on sea water quality. The research was conducted at the beginning of the rainy season (September 2019) and the beginning of the dry season (April 2020) in Pasuruan waters with three sampling locations, namely Lekok, Kraton and Nguling. The determination of the research station was based on the distribution of the Selar fish (Selaroides leptolepis) caught in the treadmill chart in Pasuruan waters as organisms identified as contaminated with heavy metals $\mathrm{Hg}, \mathrm{Pb}$ and $\mathrm{Cd}$. Supporting data for physical and chemical water quality parameters is carried out in-situ at the research location such as current, temperature, $\mathrm{DO}, \mathrm{pH}$ and salinity. Fish samples were taken and preserved in a cool box containing an ice tube for the kidneys to be taken, water samples for heavy metal measurements were put into a 600 $\mathrm{ml}$ plastic bottle from each station and put into the cool box and then the water samples and kidney samples were analyzed for heavy metals. $\mathrm{Pb}, \mathrm{Hg}$ and $\mathrm{Cd}$ were conducted at the
Chemistry Laboratory, Faculty of Mathematics and Natural Sciences, Brawijaya University, Malang. To determine the status of the water quality in the Pasuruan sea, the STORET method is used. Based on the decision of the minister of the environment the STORET method is one of the methods to determine the water quality status that is commonly used. With the STORET method [4], it can be seen the level of quality classification parameters that have met or exceeded the water quality standards. Determination of water quality status using the STORET system is intended as a reference in monitoring water quality with the aim of knowing the quality (quality) of an aquatic system. Determination of water quality status using the STORET method is carried out by the steps of a) comparing the measurement result data of each water parameter with the quality standard value according to the water class; b) if the measurement results meet the quality standard value (measurement result <quality standard) then given a score of $0, \mathrm{c}$ ) if the measurement result does not meet the water quality standard (measurement result $>$ quality standard) then the score is given as in Table 1.

Table 1. Determination of the value system to determine the status of water quality [5]

The negative sum of all parameters is calculated and the quality status is determined

\begin{tabular}{|c|c|c|c|c|}
\hline \multirow{2}{*}{$\begin{array}{l}\text { Numbe } \\
\text { r of } \\
\text { exampl } \\
\text { es }\end{array}$} & \multirow[b]{2}{*}{ Value } & \multicolumn{3}{|c|}{ Parameter } \\
\hline & & $\begin{array}{l}\text { Physi } \\
\text { cs }\end{array}$ & $\begin{array}{l}\text { Chemic } \\
\text { al }\end{array}$ & $\begin{array}{l}\text { Biolo } \\
\text { gy }\end{array}$ \\
\hline \multirow[t]{3}{*}{$<10$} & $\begin{array}{l}\text { Maxsim } \\
\text { um }\end{array}$ & -1 & -2 & -3 \\
\hline & $\begin{array}{l}\text { Minimu } \\
\mathrm{m}\end{array}$ & -1 & -2 & -3 \\
\hline & Average & -3 & -6 & -9 \\
\hline \multirow[t]{3}{*}{$>10$} & $\begin{array}{l}\text { Maxsim } \\
\text { um }\end{array}$ & -2 & -4 & -6 \\
\hline & $\begin{array}{l}\text { Minimu } \\
\mathrm{m}\end{array}$ & -2 & -4 & -6 \\
\hline & Average & -6 & -12 & -18 \\
\hline
\end{tabular}

from the total score obtained using a value system that classifies water quality into four classes, namely:

(1) Class A: very well, score $=0$ meet quality standards

(2) Class B : well, score $=-1 \mathrm{~s} / \mathrm{d}-10$ lightly polluted

(3) Class C : moderate, score $=-11 \mathrm{~s} / \mathrm{d}-30$

moderately pollute

(4) Class D: bad, score $=-31$ heavily polluted 


\section{RESULT AND DISCUSSION}

\section{Heavy Metal Content in Water}

The $\mathrm{Pb}$ quality standard for water based on [6] is $0.008 \mathrm{mg} / \mathrm{l} \mathrm{mg} / \mathrm{l}$, the quality standard for $\mathrm{Cd}$ in water based is $0.001 \mathrm{mg} / \mathrm{l}$ and the quality standard for $\mathrm{Hg}$. for water based is 0.002 $\mathrm{mg} / \mathrm{l}$. The results of heavy metals $\mathrm{Pb}, \mathrm{Cd}$ and $\mathrm{Hg}$ are presented in Figure 1.

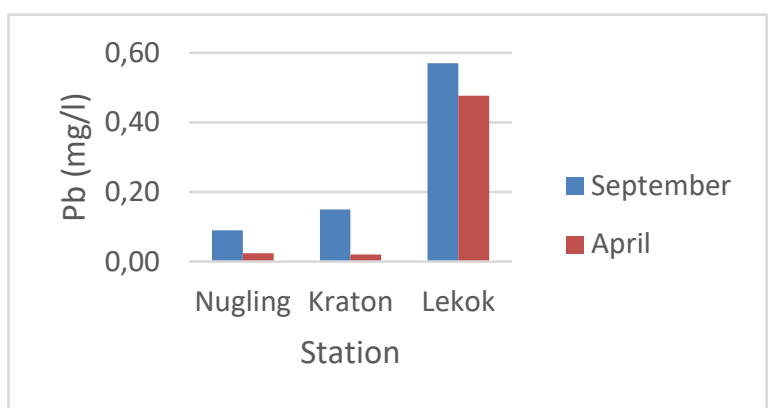

(a)

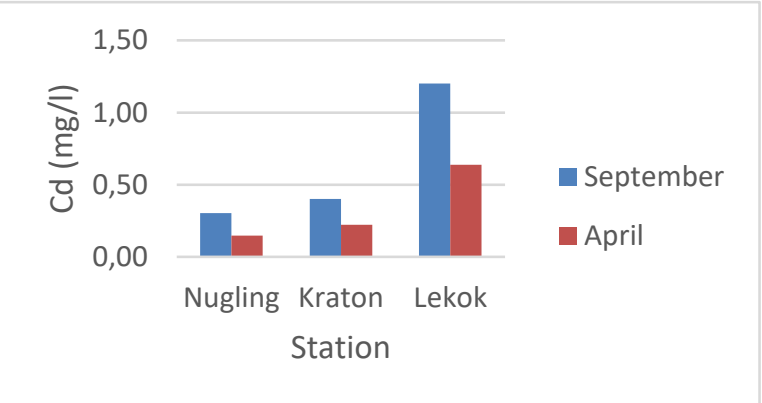

(b)

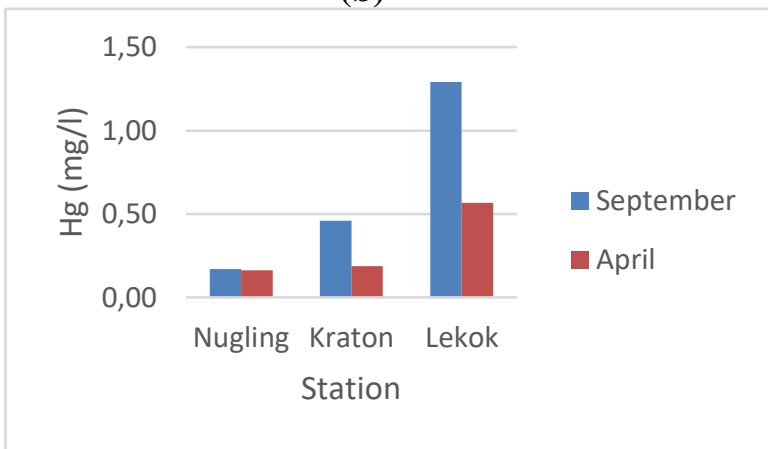

(c)

Figure 1. Concentration of Heavy Metals: a). $\mathrm{Pb}, \mathrm{b}) . \mathrm{Cd}$ and c). $\mathrm{Hg}$ in Pasuruan Waters

The dissolved $\mathrm{Pb}$ obtained during the study ranged from $0.02-0.57 \mathrm{mg} / \mathrm{l}$, the dissolved $\mathrm{Pb}$ content in the waters in the three research locations tended to be high and exceeded the government quality standards, but at Lekok Location there was a very significant value, far exceeding the quality standard which have been set. This condition is suspected because Lekok is the center of capture fisheries in Pasuruan, where many ships are anchored, which is likely to produce $\mathrm{Pb}$ waste. The dissolved $\mathrm{Cd}$ obtained during the study ranged from 0.32 to $1.2 \mathrm{mg} / \mathrm{l}$, the $\mathrm{Cd}$ content in the waters in all locations was above the quality standard set for the waters. At Lekok location there are high scores, far exceeding the predetermined quality standards. This condition is thought to be because in Lekok there is more input from anthropogenic activities than Nguling and the Kraton. Even the results of interviews with fishermen in Lekok District stated that it was suspected that many residents often littered, especially garbage. Dissolved $\mathrm{Hg}$ obtained during the study ranged from 0.19 to $1.22 \mathrm{mg} / \mathrm{l}$. At the Lekok location there was a high value, far exceeding the predetermined quality standards. This condition is thought to be because in Lekok there is more input from anthropogenic activities than Nguling and the Kraton. Disposal of waste from households, shipbuilding and ship traffic.

The high content of heavy metals in waters can cause contamination, accumulation and even pollution to the environment such as biota, sediment, water and so on. Based on their use, heavy metals can be divided into two groups, namely: Groups that in certain concentrations function as micronutrients that are beneficial to aquatic organisms, such as $\mathrm{Zn}$, $\mathrm{Fe}, \mathrm{Cu}, \mathrm{Co}$ and metals that have no known benefits for aquatic organisms, such as $\mathrm{Hg}, \mathrm{Cd}$, and $\mathrm{Pb}$ [7].

The high condition of heavy metals $(\mathrm{Pb}$, $\mathrm{Cd}, \mathrm{Hg}$ ) in Lekok waters needs to be watched out because heavy metals that enter the waters will spread and accumulate in sediments, then will accumulate in the bodies of aquatic organisms. Apart from this, $\mathrm{Pb}$ is a heavy metal that is persistent, so that if it contaminates living things it will endanger the body. That heavy metal concentrations that are not lethal (chronic, not lethal dose) will cause damage to body organs, especially organs related to immunity. In addition to causing damage to various organs of the body, it will also disrupt physiological processes in the body of the biota and can even cause reproduction problems and can cause congenital defects in the embryo.

\section{Hg Content in Selar Fish Kidneys}

Mercury metal $(\mathrm{Hg})$ against the kidneys of Selar fish (Selaroides leptolepis) obtained from Pasuruan waters, at the sampling points in 
Nguling, Lekok and Kraton in September and April (Figure 2) the highest average was found in September and in Selar Fish Kidneys which originated from Lekok in September with a value of $6.81 \mathrm{mg} / \mathrm{kg}$ higher than the nguling and kraton locations, namely 3.1 and 2.8 $\mathrm{mg} / \mathrm{kg}$. And also, the highest value in April during the dry season is also at the winding location, which is $2 \mathrm{mg} / \mathrm{kg}$ compared to 2 other locations, namely nguling and kraton with values of 1.1 and $1.4 \mathrm{mg} / \mathrm{kg}$.

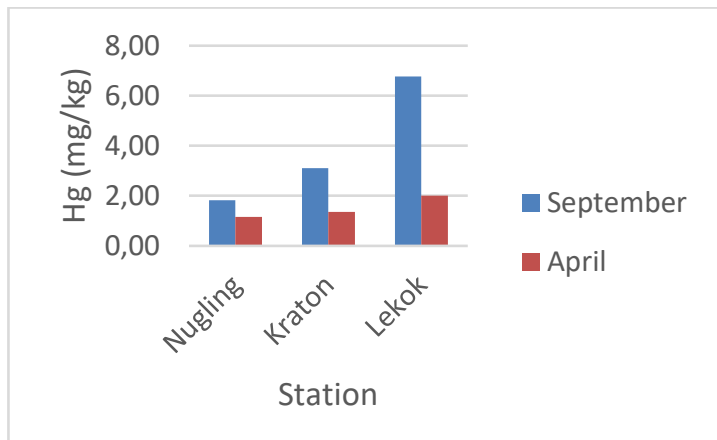

Figure 2. Hg levels in the kidneys of Selaroides leptolepis fish

Mercury metal $(\mathrm{Hg})$ is a heavy metal that is most commonly found in the environment, especially aquatic environments, and has a high toxic effect, even at low concentrations and is a toxic substance that causes chronic poisoning in humans. In waters mercury comes from several sources, namely natural sources, mining and industry. High yields of $\mathrm{Hg}$ metal in the kidneys of selar fish are obtained during September or during the rainy season because the levels of heavy metals found in the water are also high in that month so that accumulation in the kidneys is also high. According to [8] the threshold for mercury $(\mathrm{Hg})$ in water is $0.02 \mathrm{mg} / \mathrm{l}$ and in fish is 0.5 $\mathrm{mg} / \mathrm{kg}$. Based on the results obtained, the kidneys passed the threshold because all of them had an average value of more than 0.5 $\mathrm{mg} / \mathrm{kg}$. Mercury is a dangerous heavy metal because this element has a high risk to blood vessels. Mercury enters the body, most of it will be collected in the kidneys, liver and some is excreted through the digestive tract. Mercury can affect the smooth muscle of blood vessels directly or indirectly through the kidneys, resulting in changes.

Mercury can enter the bodies of aquatic organisms in three ways: through the food chain, skin surface diffusion and through gills. Of the three ways, the most likely for mercury to enter the body is through the food chain, because nearly $90 \%$ of the toxic material or heavy metal mercury enters the body. In this process, phytoplankton plays an important role in which phytoplankton will absorb organic mercury during photosynthesis. Mercury is a lipophilic substance, with this characteristic, mercury easily diffuses through the skin membrane and then enters the body's tissues [9]. Heavy metals are essential for maintaining a variety of biochemical and physiological functions in living organisms when in very low concentrations, but become dangerous when they exceed certain thresholds. The heavy metal binds to the protein site which should not be entered, then the original metal from its natural binding site is removed causing cell damage [10]. Heavy metals that accumulate in the body of living organisms will be more easily stored than broken down or excreted. Heavy metals $\mathrm{Pb}$ and $\mathrm{Cd}$ enter the most toxic metals for organisms. These heavy metals bind to specific enzymes and proteins required for cellular function, and thus compete with other important substances for the maintenance and continued function of cells [11].

\section{Water Quality and Storet Index}

The temperature during the study ranged from 28.6-29.4 ${ }^{\circ} \mathrm{C}$. The resulting water temperature is still close to the optimum temperature for fish growth in general, namely 25-30 ${ }^{\circ} \mathrm{C}$. Temperature measurements are carried out in the morning before noon while exploring station points. In connection with the diet of Selaroides leptolepis fish, namely plankton, the temperature range also supports the growth of phytoplankton in waters with a range between $20^{\circ} \mathrm{C}-30{ }^{\circ} \mathrm{C}$ [12].

The observed current velocity ranged from $0.02-0.07 \mathrm{~m} / \mathrm{s}$. The movement of currents in coastal areas tends to be dominated by tidal conditions. The movement of water tends to move towards land at high tide. Apart from tides, moving winds will have an effect of about $2 \%$ of their speed on surface currents, and as depth increases, the influence of the winds on currents will decrease [13].

The $\mathrm{pH}$ value obtained at all stations and points is relatively the same. Marine waters generally have a $\mathrm{pH}$ range between 6.5-9.0. The degree of acidity is very important in determining the use value of waters for organisms and other purposes, generally influenced by several factors such as 
photosynthetic activity, temperature and the presence of cation anions. Fish and other aquatic biota can still tolerate aquatic environments that have a $\mathrm{pH}$ value between 4.0-11.0 [14].

The salinity values obtained during the study ranged from 28.4-33.5 ppt. Salinity in Kraton waters is lower between Lekok and Nguling points of collection because these waters are close to the river mouth. Factors that influence the difference in salinity values are weather, wind and the influence of land, such as mixing with fresh water carried by rivers and waste from settlements [15].

Dissolved oxygen obtained during the study ranged from 6.2-8.3 mg/l. Dissolved oxygen content of more than $5 \mathrm{mg} / \mathrm{l}$, almost all aquatic organisms like this condition, as well as yellow selar fish (Selaroides leptolepis), fish need dissolved oxygen in sufficient quantities to carry out physiological activities [16].

Table 2. The Scoring Results for Pasuruan Waters Storetic Index in September 2019 (Rainy Season) and April 2020 (Dry Season) shipbuilding and ship traffic. The yield of heavy metals $(\mathrm{Pb}, \mathrm{Hg}$ and $\mathrm{Cd})$ also tends to be higher in September or the beginning of the rainy season, which should be during the rainy season to reduce the concentration of heavy metals in waters, this is stated by [17], High rainfall is synonymous with increasing water discharge which can accelerate the purification process. Discharge is a diluting factor, the higher the discharge that passes through the river, the lower the concentration of dissolved heavy metals. Decreasing river water discharge, causing concentrations of pollutant concentrations in the water. However, in reality, there was an increase in heavy metal concentrations in the rainy season (September). The results of interviews by researchers with fishermen in Pasuruan waters, there are indications that there are still many people (industries) pouring heavy metal-containing waste into the waters on rainy days, so that the concentration of pollutants, especially those that enter B3 waste such as heavy metals, increases. in the rainy season. The high and low concentrations of heavy metals in

\begin{tabular}{|c|c|c|c|c|c|c|c|c|c|c|c|c|}
\hline Rainy & \multicolumn{4}{|c|}{ Nguling } & \multicolumn{4}{|c|}{ Kraton } & \multicolumn{4}{|c|}{ Lekok } \\
\hline & $\max$ & $\min$ & average & score & $\max$ & $\min$ & \begin{tabular}{|l} 
average \\
\end{tabular} & score & $\max$ & $\min$ & avrg & Score \\
\hline $\mathrm{pH}$ & 0 & 0 & 0 & 0 & 0 & 0 & 0 & 0 & 0 & 0 & 0 & 0 \\
\hline $\begin{array}{l}\text { Tempera } \\
\text { ture }\end{array}$ & 0 & 0 & 0 & 0 & 0 & 0 & 0 & 0 & 0 & 0 & 0 & 0 \\
\hline DO & 0 & 0 & 0 & 0 & 0 & 0 & 0 & 0 & 0 & 0 & 0 & 0 \\
\hline Salinity & 0 & 0 & 0 & 0 & 0 & 0 & 0 & 0 & 0 & 0 & 0 & 0 \\
\hline $\mathrm{Pb}$ & 0 & 0 & 0 & 0 & -2 & 0 & -6 & -8 & -2 & 0 & -6 & -8 \\
\hline $\mathrm{Hg}$ & -2 & 0 & -6 & -8 & -2 & 0 & -6 & -8 & -2 & 0 & -6 & -8 \\
\hline $\mathrm{Cd}$ & -2 & 0 & -6 & -8 & -2 & 0 & -6 & -8 & -2 & 0 & -6 & -8 \\
\hline Status & \multicolumn{3}{|c|}{ Moderately polluted } & -16 & \multicolumn{4}{|c|}{ Moderately polluted } & \multicolumn{3}{|c|}{ Moderately polluted } & -24 \\
\hline Dry & \multicolumn{4}{|c|}{ Nguling } & \multicolumn{4}{|c|}{ Kraton } & \multicolumn{4}{|c|}{ Lekok } \\
\hline Season & $\max$ & $\min$ & average & score & $\max$ & $\min$ & average & score & $\max$ & $\min$ & avrg & Score \\
\hline $\mathrm{pH}$ & 0 & 0 & 0 & 0 & 0 & 0 & 0 & 0 & 0 & 0 & 0 & 0 \\
\hline $\begin{array}{l}\text { Tempera } \\
\text { ture }\end{array}$ & 0 & 0 & 0 & 0 & 0 & 0 & 0 & 0 & 0 & 0 & 0 & 0 \\
\hline DO & 0 & 0 & 0 & 0 & 0 & 0 & 0 & 0 & 0 & 0 & 0 & 0 \\
\hline Salinity & 0 & 0 & 0 & 0 & 0 & 0 & 0 & 0 & 0 & 0 & 0 & 0 \\
\hline $\mathrm{Pb}$ & 0 & 0 & 0 & 0 & 0 & 0 & 0 & 0 & -2 & 0 & -6 & -8 \\
\hline $\mathrm{Hg}$ & -2 & 0 & -6 & -8 & -2 & 0 & -6 & -8 & -2 & 0 & -6 & -8 \\
\hline $\mathrm{Cd}$ & -2 & 0 & -6 & -8 & -2 & 0 & -6 & -8 & -2 & 0 & -6 & -8 \\
\hline Status & \multicolumn{3}{|c|}{ Moderately polluted } & -16 & \multicolumn{3}{|c|}{ Moderately polluted } & -16 & \multicolumn{3}{|c|}{ Moderately polluted } & -24 \\
\hline
\end{tabular}

Water pollution in the Pasuruan sea is classified as medium polluted with a high average in September during the rainy season in Lekok waters, this condition is suspected because in Lekok there are more inputs from anthropogenic activities than Nguling and Kraton. Disposal of waste from households,
Pasuruan waters are caused by domestic activities, industrial factories and transportation activities. Stated that the largest source of $\mathrm{Pb}$ metal contaminants is lead additive gasoline for motor vehicle fuel and agricultural activities. Meanwhile, Cd metal in nature comes from industrial waste from metals, plastics, paints, fertilizers and oil [18]. 
Those anthropogenic inputs, such as industrialization, urbanization, and industrial waste deposition are the main contributors to the enrichment of metals in water.

The difference in concentrations of heavy metals $\mathrm{Pb}, \mathrm{Cd}$, and $\mathrm{Hg}$ in marine waters between summer and rainy season is influenced by various factors. Among them are physical processes. Physical processes are influenced by environmental conditions such as currents which affect the rate of deposition. In the rainy season, it is suspected that the current causes friction between the sediment surface and the water mass. This causes the release of particles in the sediment to the water column, thus potentially reducing or increasing the concentration of heavy metals in suspended particles. The amount of heavy metal content in these waters is still below the international standard quality standard according to [19] for Metals in Sediments, namely with a maximum concentration of $85 \mathrm{mg} / \mathrm{l}$.

\section{CONCLUSION}

The conclusion obtained from the status of water quality in Pasuruan waters is that the heavy metal content obtained exceeds the government quality standard so that based on the storet index, Pasuruan waters are included in the lightly polluted category in September 2019 during the rainy season and in April 2020 during the dry season at the three stations. The research locations are Lekok, Kraton and Nguling so that better management is needed so that the pollution status in Pasuruan waters does not get worse.

\section{REFERENCES}

[1] Fuad, S. Sukandar, and A. Jauhari, "Development of Underwater Lights as Auxiliary Devices on a Plug-in Chart in Tambak Lekok Village, Lekok District, Pasuruan," J. Kelaut. Indones. J. Mar. Sci. Technol., vol. 9, no. 1, p. 7, 2016, doi: 10.21107/jk.v9i1.1007.

[2] Haryono, M., Mulyanto, and Y. Kilawati, "Content of heavy metals $\mathrm{Pb}$ sea water, sediment and green shell meat Perna viridis," J. Ilmu dan Teknol. Kelaut. Trop., vol. 9, no. 1, pp. 1-7, 2017, [Online]. Available: http://www.tjyybjb.ac.cn/CN/article/do wnloadArticleFile.do?attachType=PD F\&id=9987.
[3] Muslimah, H. "Accumulated heavy metals $\mathrm{Pb}, \mathrm{Cd}$, and $\mathrm{Hg}$ in Feather Shellfish (Anadara antiquata) and blood shells (Anadara granosa) in Lekok beach waters, Pasuruan Regency," J. Chem. Inf. Model., vol. 53, no. 9, pp. 1689-1699, 2013.

[4] Decree of the Minister of the Environment "concerning Guidelines for Determining the Status of Water Quality" Number 115, 2003

[5] Said, N.I. "Heavy metal removal methods (As, $\mathrm{Cd}, \mathrm{Cr}, \mathrm{Ag}, \mathrm{Cu}, \mathrm{Pb}, \mathrm{Ni}$ and $\mathrm{Zn}$ ) in industrial wastewater," J. Air Indones., vol. 6, no. 2, pp. 136-148, 2010, doi: 10.29122/jai.v6i2.2464.

[6] Indonesia Government Regulation of the Republic of Indonesia No. 82 of 2001 concerning Water Quality Management and Water Pollution Control. Indonesia, Jakarta. 2001.

[7] Riani, E., H. S. Johari, and M. R. Cordova, "Bioaccumulation of Cadmium and Lead in Prickly Pen Shell in Seribu Archipelago," J. Pengolah. Has. Perikan. Indones., vol. 20, no. 1, p. 131, 2017, doi: 10.17844/jphpi.v20i1.16500.

[8] National Standardization Agency. SNI 7387: 2009. Maximum Limit of Metal Contamination Weight in Food.2009.

[9] Jaishankar, M., T. Tseten, N. Anbalagan, B. B. Mathew, and K. N. Beeregowda, "Toxicity, mechanism and health effects of some heavy metals," Interdiscip. Toxicol., vol. 7, no. 2, pp. 60-72, 2014, doi: 10.2478/intox-2014-0009.

[10] Govind, P.S.M "Heavy Metals Causing Toxicity in Animals and Fishes," Res. J. Anim. Res. J. Anim. Vet. Fish. Sci. Int. Sci. Congr. Assoc., vol. 2, no. 2, pp. 1723, 2014.

[11] Boyd, C.E and F. Lichtkoppler, "Water Quality Management in pond fish culture Research and Development Series," Int. Cent. Aquac., vol. 22, no. 22, pp. 1-30, 1979. 
[12] Bayhaqi, A.,M. R. Iskandar, and D. Surinati, "Surface Current Patterns and Physical Conditions of the Waters Around Selayar Island in Transitional Season 1 and East Season," Oseanologi dan Limnol. di Indones., vol. 2, no. 1, p. 83, 2017, doi: 10.14203/oldi.2017.v2i1.71.

[13] Siburian, R., L. Simatupang, and M. Bukit, "Analysis of the Quality of Sea Waters on Activities in the Port of Waingapu-Alor, East Sumba," $J$. Pengabdi. Kpd. Masy., vol. 23, no. 1, p. 225, 2017, doi: 10.24114/jpkm.v23i1.6639.

[14] Souhoka, J and S. I. Patty, "Monitoring of Hydrological Conditions in Relation to Coral Reef Conditions in the Waters of Talise Island, North Sulawesi," J. Ilm. Platax, vol. 1, no. 3, pp. 138-147, 2013.

[15] Rahman, A M and Y. Dhahiyat, "Distribution of heavy metal content $\mathrm{Pb}$ and $\mathrm{Cd}$ in the water column and sediment of the upstream Citarum River Basin," J. Perikan. dan Kelaut. Unpad, vol. 3, no. 3, pp. 175-182, 2012.

[16] Azhar,H., I. Widowati, and J. Suprijanto, "Study of heavy metal content of $\mathrm{Pb}, \mathrm{Cu}, \mathrm{Cd}, \mathrm{Cr}$ in scallop shells (Amusium pleuronectes), water and sediment in Wedung waters, Demak Regency," J. Mar. Res., vol. 1, no. 2, pp. 35-44, 2012, [Online]. Available:

https://doi.org/10.14710/jmr.v1i2.2017

[17] Islam, M. S., M. K. Ahmed, M. Raknuzzaman, M. Habibullah -AlMamun, and M. K. Islam, "Heavy metal pollution in surface water and sediment: A preliminary assessment of an urban river in a developing country," Ecol. Indic., vol. 48, pp. 282-291, 2015 , doi: 10.1016/j.ecolind.2014.08.016.

[18] B Hamuna, B., R. H. R. Tanjung, S. Suwito, H. K. Maury, and A. Alianto, "Study of Seawater Quality and Pollution Index Based on PhysicalChemical Parameters in the Waters of the Depapre District, Jayapura," J. Ilmu Lingkung., vol. 16, no. 1, p. 35, 2018, doi: 10.14710/jil.16.1.35-43.

[19] CCME (Canadian Council of Ministers of the Environment). Canadian Sediment Quality Guidelines for the Protection of Aquatic Life. 2001. 